\title{
Peremajaan Kelapa Sawit (Elaeis guineensis Jacq.) di Seruyan Estate, Minamas Plantation Group, Seruyan, Kalimantan Tengah
}

\author{
Replanting of Palm Oil (Elaeis guineensis Jacq.) in Seruyan Estate, Minamas Plantation Group, \\ Seruyan, Central Borneo
}

Wisnu Hari Wibowo dan Ahmad Junaedi*

Departemen Agronomi dan Hortikultura, Fakultas Pertanian, Institut Pertanian Bogor

(Bogor Agricultural University), Jl. Meranti, Kampus IPB Darmaga, Bogor 16680, Indonesia

Telp.\&Faks.62-251-8629353 e-mail agronipb@indo.net.id

"Penulis untuk korespondensi : ajunaedi@yahoo.co.id

Disetujui 16 Januari 2017/ Published Online 24 Januari 2017

\begin{abstract}
This research conducted in Seruyan Estate from February to June 2016. The purpose of the internship was to learn the technical and managerial aspects of the palm oil replanting and to analyze the compliance with the RSPO and ISPO criteria during the replanting activity. Observations made include the right steps of replanting based on standards that established by the company, machine job performance, and employee performance. The observations then analyzed descriptively based on standards that applied to the replanting program. The results showed that the phase of replanting was divided into two phases: the land preparation that includes palm oil census, stacking spot setting, felling, chipping, stacking, deboling, closing the deboling hole, road construction; and the planting stage that includes the setting of planting spot, planting LCC, hole digging and palm oil planting. Seruyan Estate met the criteria of RSPO and ISPO in term of the obligation to conserve the High Conservation Value Area. In addition, the replanting program in Seruyan Estate also didn't use fire for the land preparation.
\end{abstract}

Keywords : conservation, job performance, land preparation

\section{ABSTRAK}

Kegiatan penelitian ini dilaksanakan di Seruyan Estate dari Februari hingga Juni 2016. Kegiatan magang ini bertujuan untuk mempelajari aspek teknis dan manajerial peremajaan kelapa sawit dan menganalisis kesesuaiannya dengan kriteria RSPO dan ISPO saat kegiatan replanting. Pengamatan yang dilakukan meliputi tahap-tahap peremajaan yang tepat berdasarkan standar yang telah ditetapkan perusahaan, prestasi kerja alat, dan prestasi kerja karyawan. Hasil pengamatan tersebut kemudian dianalisis secara deskriptif berdasarkan standar yang berlaku pada kegiatan peremajaan. Hasil pengamatan menunjukkan bahwa tahap peremajaan dibagi menjadi dua tahap, yaitu tahap persiapan lahan yang meliputi sensus pokok, pancang rumpuk, penumbangan, pencincangan, merumpuk pokok, deboling, tutup lubang deboling, pembuatan jalan kontur; dan tahap penanaman yang meliputi pemancangan titik tanam, penanaman kacangan penutup tanah, pembuatan lubang tanam, dan penanaman tanaman kelapa sawit. Seruyan Estate telah memenuhi kriteria RSPO dan ISPO dikarenakan adanya kewajiban mengelola area Nilai Konservasi Tinggi di dalam kebun. Selain itu, kegiatan peremajaan di Seruyan Estate juga tidak menggunakan api saat melakukan persiapan lahan.

Kata kunci : konservasi, persiapan lahan, prestasi kerja 


\section{PENDAHULUAN}

Pasar industri kelapa sawit (Elaeis guineensis Jacq.) yang baik dan berkelanjutan dapat dicapai apabila perusahaan memiliki stabilitas di dalam produksinya. Oleh karena itu, dalam rangka meningkatkan produksi atau stabilitas produksi, teknik dalam pembudidayaan kelapa sawit menjadi penting. Menurut Setyamidjaja (2006), teknik budidaya kelapa sawit terdiri dari beberapa tahap, antara lain pembibitan, pembukaan lahan, rancangan kebun, penanaman, tanaman penutup tanah, pemeliharaan tanaman belum menghasilkan (TBM), pemeliharaan tanaman menghasilkan (TM), dan peremajaan.

Salah satu kegiatan yang penting dalam teknik budidaya adalah peremajaan. Program peremajaan tanaman harus disiapkan dengan baik, khususnya pada perkebunan plasma. Menurut Hutasoit et al. (2015), persepsi petani terhadap kegiatan peremajaan sangat baik. Hal ini berimplikasi pada tingginya tingkat kesiapan petani untuk melakukan peremajaan kelapa sawit saat umur tanaman kelapa sawit sudah tidak produktif lagi. Petani telah mengetahui pentingnya peremajaan untuk menjaga keberlanjutan usaha perkebunan kelapa sawit. Petani juga telah memperoleh berbagai pelatihan mengenai pentingnya kegiatan peremajaan bagi keberlanjutan usaha perkebunan kelapa sawit yang lestari.

Penelitian yang dilakukan Susanti et al. (2014) menyatakan bahwa alternatif model peremajaan underplanting mampu memberikan keuntungan secara finansial dibandingkan model peremajaan intercropping (tanaman sela). Peremajaan model underplanting telah dinilai lebih efektif dan efisien. Model ini menebang tanaman tua secara bertahap atau tidak secara keseluruhan sehingga memungkinkan perusahaan tidak kehilangan pendapatan selama tanaman yang diremajakan belum menghasilkan karena masih tersedianya pendapatan dari tanaman tua yang disisakan.

Peremajaan dilakukan berdasarkan teori produksi kelapa sawit. Data yang diperoleh dari BPS (2014) menunjukkan pada tahun 2014 luas lahan perkebunan besar kelapa sawit seluas 10.9 juta ha. Secara teoritis, produksi tanaman kelapa sawit per satuan luas menunjukkan kecenderungan yang meningkat secara tajam pada umur 4-7 tahun, melandai pada umur 8-15 tahun, dan mulai turun pada umur $>16$ tahun. Teori tersebut secara tidak langsung menyatakan bahwa produksi per hektar per tahun kelapa sawit akan optimal jika umur tanaman rata-rata 15 tahun. Acuan ini didasarkan karena pada umur 15 tahun akan tercapai produksi puncak pada tanaman. Keadaan produksi yang maksimal sepanjang siklus tanaman juga akan menjadikan semua fixed cost yang harus ditanggung perusahaan akan berfungsi secara optimal (Pahan, 2008). Menurut Nurkhoiry et al. (2006) pertimbangan suatu kebun saat akan melakukan peremajaan adalah melihat produktivitas tanaman dalam kebun tersebut terlebih dahulu, meliputi kerapatan tanaman per hektar dan serangan hama penyakit. Apabila produktivitas tanaman di bawah standar yang telah ditetapkan perusahaan, maka perlu diadakan peremajaan. Selain itu, peremajaan juga dapat dipertimbangkan apabila panen sulit dilakukan akibat tanaman yang sudah terlalu tinggi.

Hasil peremajaan yang baik tidak hanya berdasarkan perencanaan dan teknik yang baik, namun juga berdasarkan tanggung jawab perusahaan terhadap lingkungan di sekitarnya. Penerapan tanggung jawab terhadap lingkungan pada perkebunan kelapa sawit ini tercantum pada prinsip RSPO (Roundtable on Sustainable Palm Oil) sebagai organisasi yang bertujuan untuk mendorong perluasan sektor kelapa sawit yang lebih memperhatikan aspek lingkungan untuk memenuhi permintaan minyak dan lemak kelapa sawit global. Selain itu, RSPO juga dibentuk untuk menetralkan isu-isu negatif perusahaan kelapa sawit terkait pencemaran lingkungan (Colchester et al., 2006). Indonesia juga secara khusus memiliki sertifikasi untuk kelapa sawit yang berkelanjutan yang disebut ISPO (Indonesia Sustainable Palm Oil). Berbeda dengan RSPO yang bersifat sukarela, sertifikasi ISPO wajib dimiliki oleh seluruh perusahaan kelapa sawit di Indonesia. ISPO dibentuk berdasarkan kesadaran pemerintah bahwa pengelolaan kelapa sawit di Indonesia juga harus dilakukan secara berkelanjutan.

Secara umum, tujuan dari kegiatan penelitian antara lain memperoleh pengalaman serta meningkatkan kemampuan teknis dan manajerial, meningkatkan keterampilan mahasiswa dalam praktek kerja yang nyata, dan memperluas wawasan dalam pengelolaan perkebunan kelapa sawit. Tujuan khusus dari kegiatan penelitian yang dilaksanakan antara lain melakukan observasi teknis-teknis kegiatan peremajaan dan menganalisis kesesuaiannya dengan kriteria RSPO dan ISPO pada kegiatan peremajaan.

\section{METODE PENELITIAN}

Kegiatan penelitian ini dilaksanakan selama empat bulan mulai dari bulan Februari sampai Juni 2016 bertempat di Seruyan Estate, 
Kabupaten Seruyan, Provinsi Kalimantan Tengah. Kegiatan penelitian yang dilakukan terdiri dari dua aspek, yaitu aspek teknis dan aspek manajerial. Aspek teknis adalah kegiatan di lapangan sebagai Karyawan Harian Lepas (KHL), sedangkan aspek manajerial berupa kegiatan sebagai pendamping mandor dan pendamping asisten kebun.

Metode dalam kegiatan penelitian adalah metode langsung dan tidak langsung yang digunakan untuk memperoleh data-data primer dan sekunder. Metode langsung yang dilakukan adalah praktek kerja di lapangan dengan mengikuti pelaksanaan kegiatan teknis dan manajerial perusahaan dan melakukan wawancara ataupun diskusi dengan para staf dan pekerja kebun. Metode tidak langsung dilakukan dengan mengumpulkan data berdasarkan laporan harian, bulanan, dan tahunan dari arsip kebun.

Kegiatan penelitian pada satu bulan pertama adalah sebagai Karyawan Harian Lepas (KHL), satu bulan kemudian menjadi pendamping mandor, dan dua bulan setelahnya menjadi pendamping asisten kebun. Kegiatan selama menjadi KHL meliputi kerjasama dengan KHL lainnya untuk melakukan kegiatan sesuai yang diperintahkan oleh mandor, antara lain kegiatan peremajaan, pembibitan, pemeliharaan, pemanenan, dan kegiatan lainnya. Kegiatan selama menjadi pendamping mandor meliputi mempelajari batas kewenangan seorang mandor yang diantaranya adalah menentukan kebutuhan tenaga kerja, menentukan daerah yang akan dilakukan pemeliharaan, menghitung prestasi kerja tenaga kerja, dan lain-lain. Sebagai pendamping asisten kebun, penulis mempelajari aspek manajerial berupa cara memimpin tenaga kerja yang berada pada tingkat divisi.

Pengamatan mengenai sistem peremajaan meliputi urutan pekerjaan peremajaan dan jenisjenis pekerjaan pada peremajaan. Pekerjaan pada kegiatan peremajaan menurut Pahan (2008) antara lain adalah

1. Pemancangan

2. Pembuatan parit (pada daerah rendah)

3. Pembuatan jaringan jalan

4. Pembuatan lubang tanam

5. Pembongkaran pokok

6. Penyemprotan gawangan dengan herbisida

7. Sorong batang dari lubang tanaman dan teras

8. Penanaman kacang-kacangan penutup tanah

9. Penanaman kelapa sawit

Pengamatan kegiatan peremajaan dilakukan sesuai dengan Panduan untuk memenuhi Prinsip dan Kriteria RSPO untuk produksi minyak sawit berkelanjutan (Global Sustainability Associated, 2014) dan Permentan
Republik Indonesia nomor 11/Permentan/OT.140/3/2015 tentang Sistem Sertifikasi Kelapa Sawit Berkelanjutan (Departemen Pertanian, 2015), yaitu

1. Praktik-praktik meminimalkan dan mengontrol erosi dan degradasi tanah. (RSPO poin 4.3)

2. Status spesies langka, terancam, atau terancam punah dan habitat dengan Nilai Konservasi Tinggi lainnya, apabila ada yang terdapat dalam perkebunan atau yang dapat terpengaruh oleh manajemen perkebunan atau pabrik minyak sawit, harus diidentifikasi dan kegiatan operasional harus dikelola sedemikian rupa untuk menjamin bahwa spesies dan habitat tersebut terjaga dan/atau terlindungi dengan baik. (RSPO poin 5.2)

3. Penggunaan metode pembakaran untuk membuka lahan atau menanam ulang dihindari, kecuali dalam situasi khusus sebagaimana telahdiidentifikasi dalam pedoman ASEAN atau praktik terbaik egional lainnya. (RSPO poin 5.5)

4. Perusahaan Perkebunan dalam melakukan penanaman harus menggunakan benih unggul. (ISPO poin 2.2.3)

5. Perusahaan Perkebunan harus menjaga dan melestarikan keanekaragaman hayati pada areal yang dikelola. (ISPO poin 4.6)

6. Perusahaan Perkebunan harus melakukan koservasi lahan dan menghindari erosi sesuai peraturan perundang-undangan. (ISPO poin 4.9)

Pengamatan dilakukan dengan mengamati prestasi kerja alat berat yang digunakan dan prestasi kerja karyawan di lapangan. Prestasi kerja alat berat dapat diperoleh berdasarkan besarnya satuan yang dikerjakan alat berat tersebut per satuan waktu dan prestasi kerja karyawan di lapangan berdasarkan luasan lahan yang dikerjakan per HK.

Data yang diperoleh dalam kegiatan penelitian adalah data primer dan data sekunder. Data primer diperoleh dengan metode langsung, artinya penulis bekerja langsung di lapangan sebagai Karyawan Harian Lepas (KHL), pendamping mandor, pendamping asisten kebun, dan sebagai pengamat di lapangan. Pengamatan data primer di lapangan sebagian dipusatkan pada kegiatan peremajaan meliputi aspek teknis dan manajerial dari kegiatan peremajaan dan sebagian lagi pada kegiatan pemeliharaan, pemanenan, dan kegiatan-kegiatan lainnya. Data primer juga didapatkan dari wawancara langsung dengan pekerja kebun. Data-data sekunder diperoleh dari telaah pustaka mengenai kondisi umum kebun yang berupa lokasi kebun, letak geografis, ketinggian, keadaan iklim, keadaan tanah, luas 
areal perkebunan dan tata guna lahan, serta arsiparsip kebun yang berhubungan dengan kegiatan yang dilaksanakan.

Analisis data dan informasi secara keseluruhan diperoleh dari data jumlah Hari Orang Kerja (HOK), prestasi kerja, dan hari kerja optimum yang kemudian dibandingkan dengan standar kerja perusahaan tempat penelitian tersebut. Hasil kegiatan ini kemudian dianalisis menggunakan analisis deskriptif dengan membandingkan standar yang berlaku meliputi ISPO dan RSPO. Data tersebut akan dianalisis untuk mengetahui faktor-fakor yang mempengaruhi peremajaan pada perkebunan kelapa sawit dan standar yang telah diterapkan oleh perusahaan.

\section{HASIL DAN PEMBAHASAN}

\section{Kondisi Umum}

Seruyan Estate secara geografis terletak antara 2.391-2.471 ${ }^{\circ} \mathrm{LS}$ dan 111.984-112.083 ${ }^{\circ} \mathrm{BT}$ yang terletak di Desa Pembuang Hulu II, Kecamatan Hanau, Kabupaten Seruyan, Kalimantan Tengah. Luas areal Hak Guna Usaha (HGU) di kebun Seruyan Estate adalah 3.233,466 ha yang terbagi menjadi 3 divisi yaitu Divisi 1 seluas 965,998 ha, Divisi 2 seluas 1.075,444 ha, dan Divisi 3 seluas 1.023,744 ha. Tanaman kelapa sawit yang diusahakan di Seruyan Estate adalah varietas Marihat yang diproduksi oleh Pusat Penelitian Kelapa Sawit (PPKS) dan varietas Socfindo yang diproduksi oleh PT. Socfindo. Seruyan Estate saat ini memiliki enam variasi tahun tanam, yaitu tahun 1992, 1993, 1994, 2013, 2014, dan 2015. Data produksi dan produktivitas Kebun Seruyan Estate dapat dilihat pada Tabel 1.

Tabel 1. Produksi dan Produktivitas Kebun Seruyan Estate tahun 2011-2015

\begin{tabular}{cccccc}
\hline Tahun & $\begin{array}{c}\text { Luas lahan } \\
\text { (ha) }\end{array}$ & $\begin{array}{c}\text { Produksi TBS } \\
\text { (janjang) }\end{array}$ & $\begin{array}{c}\text { Produksi } \\
\text { (ton) }\end{array}$ & $\begin{array}{c}\text { Produktivitas } \\
\text { (ton.ha }^{-1} \text { ) }\end{array}$ & $\begin{array}{c}\text { BJR } \\
(\mathrm{kg})\end{array}$ \\
\hline 2011 & 3231.106 & 4743117 & 103316.83 & 31.76 & 21.78 \\
2012 & 3231.106 & 3566377 & 81092.99 & 24.93 & 22.74 \\
2013 & 3231.106 & 4320321 & 91908.26 & 30.97 & 21.27 \\
2014 & 2641.382 & 3763872 & 81503.90 & 30.45 & 21.65 \\
2015 & 2359.512 & 3213446 & 62102.60 & 26.24 & 19.33 \\
\hline
\end{tabular}

Tabel 1 menunjukkan bahwa produksi kelapa sawit di Seruyan Estate sempat mengalami penurunan dan kenaikan. Produksi kebun mengalami penurunan dari tahun 2011 ke tahun 2012, namun pada tahun 2013 produksi kembali naik walaupun tidak sebanyak tahun 2011. Luas lahan pada tahun 2014 dan 2015 mengalami penurunan dikarenakan adanya aktivitas peremajaan.

Keadaan iklim Seruyan Estate menurut klasifikasi Schmidth-Ferguson termasuk dalam tipe iklim A (sangat basah). Curah hujan selama 5 tahun terakhir (2011-2015) di Seruyan Estate memiliki rata-rata $2569 \mathrm{~mm} /$ tahun dengan hari hujan rata-rata 174 hari. Kondisi lahan di Seruyan Estate pada umumnya memiliki topografi relatif datar dengan kemiringan 0-8\% dan sebagian kecil memiliki topografi gelombang berbukit dengan kemiringan $8-15 \%$. Jenis tanah di Seruyan Estate sebagian terdiri atas tanah ultisol sebanyak 94.4\% dan sebagian kecil terdiri atas tanah spodosol sebanyak $5.6 \%$.

\section{Perencanaan Peremajaan}

Peremajaan kelapa sawit merupakan kegiatan penggantian tanaman kelapa sawit tua yang sudah tidak ekonomis lagi dengan tanaman kelapa sawit baru. Tahap pertama dalam kegiatan peremajaan yaitu perencanaan. Kebun akan membuat perencanaan peremajaan jangka panjang untuk mengetahui umur-umur tanaman yang sudah harus dipertimbangkan untuk diremajakan. Tabel perencanaan peremajaan jangka panjang tahun 2012-2017 di Seruyan Estate dapat dilihat pada Tabel 2. 
Tabel 2. Perencanaan peremajaan jangka panjang tahun 2012-2017

\begin{tabular}{|c|c|c|c|c|c|}
\hline No & Periode Tahun & Blok & Tahun Tanam & Luas (ha) & Total Luas (ha) \\
\hline \multirow{3}{*}{1} & \multirow{3}{*}{$2012-2013$} & E 012 & 1992 & 97.390 & \multirow{3}{*}{281.870} \\
\hline & & Е 013 & 1992 & 89.010 & \\
\hline & & E 014 & 1992 & 95.470 & \\
\hline \multirow{4}{*}{2} & \multirow{4}{*}{$2013-2014$} & $\mathrm{C} 014$ & 1992 & 58.310 & \multirow{4}{*}{275.110} \\
\hline & & D 012 & 1992 & 92.690 & \\
\hline & & D 013 & 1992 & 60.010 & \\
\hline & & D 014 & 1992 & 64.100 & \\
\hline \multirow{4}{*}{3} & \multirow{4}{*}{$2014-2015$} & B 012 & 1992 & 82.148 & \multirow{4}{*}{307.854} \\
\hline & & В 013 & 1992 & 83.772 & \\
\hline & & С 012 & 1992 & 84.693 & \\
\hline & & С 013 & 1992 & 57.241 & \\
\hline \multirow{5}{*}{4} & \multirow{5}{*}{$2015-2016$} & A 012 & 1993 & 46.625 & \multirow{5}{*}{390.927} \\
\hline & & А 013 & 1993 & 88.590 & \\
\hline & & В 014 & 1992 & 81.886 & \\
\hline & & В 015 & 1993 & 116.721 & \\
\hline & & $\mathrm{C} 015$ & 1993 & 57.105 & \\
\hline \multirow{4}{*}{5} & \multirow{4}{*}{$2016-2017$} & E 015 & 1993 & 55.539 & \multirow{4}{*}{319.120} \\
\hline & & E 016 & 1993 & 83.938 & \\
\hline & & Е 017 & 1993 & 82.560 & \\
\hline & & Е 018 & 1993 & 97.083 & \\
\hline
\end{tabular}

Teknis kegiatan dibagi menjadi dua tahap, yaitu tahap persiapan lahan dan tahap penanaman. Kegiatan-kegiatan pada tahap persiapan lahan meliputi sensus pokok, pancang rumpuk, penumbangan, pencincangan, dan merumpuk pokok, deboling, tutup lubang deboling, dan pembuatan jalan kontur. Setelah tahap persiapan lahan selesai, kegiatan pada tahap penanaman adalah pemancangan titik tanam, penanaman kacangan penutup tanah, pembuatan lubang tanam, dan penanaman tanaman kelapa sawit. Kebun Seruyan Estate melakukan peremajaan menggunakan sistem kontrak dengan perusahaan kontraktor. Perusahaan kontraktor akan membantu melaksanakan kegiatan peremajaan dari awal sampai akhir berdasarkan SPK (Surat Perjanjian Kerja) yang telah disepakati bersama. Kebun Seruyan Estate menggunakan lima alat excavator bertipe PC 200, satu alat bulldozer tipe D85E-SS dan dua alat hole digger dengan satu orang operator dan satu orang sebagai cadangan pada masing-masing alat. Tabel jadwal perencanaan teknis kegiatan peremajaan untuk blok dengan luas 57 ha di Seruyan Estate dapat dilihat pada Tabel 3.

Tabel 3. Jadwal perencanaan kegiatan peremajaan di Seruyan Estate

\begin{tabular}{|c|c|c|c|c|c|c|c|c|c|c|c|c|}
\hline \multirow{2}{*}{ No } & \multirow{2}{*}{ Kegiatan } & \multicolumn{11}{|c|}{ Minggu ke- } \\
\hline & & 12 & 3 & 4 & 5 & 6 & 7 & 8 & 9 & 10 & 11 & 12 \\
\hline 1 & Sensus pokok (maks 6 bulan sebelum tumbang) & & & & & & & & & & & \\
\hline 2 & Pancang rumpuk & & & & & & & & & & & \\
\hline 3 & Tumbang, cincang, dan rumpuk & & & & & & & & & & & \\
\hline 4 & Deboling & & & & & & & & & & & \\
\hline 5 & Pembuatan jalan kontur & & & & & & & & & & & \\
\hline 6 & Pancang titik tanam & & & & & & & & & & & \\
\hline 7 & Menanam kacangan penutup tanah & & & & & & & & & & & \\
\hline 8 & Pembuatan lubang tanam & & & & & & & & & & & \\
\hline 9 & Tanam kelapa sawit & & & & & & & & & & & \\
\hline
\end{tabular}

\section{Sensus Pokok}

Sensus pokok merupakan kegiatan peremajaan setelah perencanaan selesai dilakukan.
Kegiatan sensus pokok bertujuan untuk mengetahui jumlah pokok kelapa sawit yang masih hidup dan yang mati dalam setiap hektar, blok, dan areal tertentu sehingga dapat 
mengetahui jumlah pokok yang akan ditumbang pada tahap penumbangan. Sensus pokok dilakukan maksimal enam bulan sebelum dilakukan penumbangan. Sensus dilakukan dengan cara karyawan SKU akan memasuki setiap pasar rintis dan menghitung jumlah pokok pada setiap baris dalam setiap pasar rintis dengan prestasi kerja rata-rata $10 \mathrm{ha} / \mathrm{HK}$. Data yang diperoleh dari sensus pokok antara lain jumlah pokok hidup, pokok mati, pokok terserang penyakit Ganoderma boninense dan jumlah pokok pada areal konservasi. Menurut Susanto et al. (2006), ciri-ciri pokok yang terserang penyakit Ganoderma boninense antara lain menguningnya daun yang akan diikuti oleh mengeringnya anak daun dan pelepah dan berakhir dengan pembusukan pada daerah batang. Apabila pada saat sensus terdapat pokok yang terserang Ganoderma boninense, maka pokok tersebut akan ditumbang, dicincang, dan ditimbun dalam lubang ukuran $2 \mathrm{~m}$ x $2 \mathrm{~m} \times 1.2 \mathrm{~m}$. Perlakuan terhadap pokok yang terserang Ganoderma boninense tersebut dilakukan 6 bulan sebelum dilakukan peremajaan.

\section{Pancang Rumpuk}

Kegiatan yang dilakukan setelah mengetahui jumlah pokok yang akan ditumbang adalah penentuan titik pancang kepala/utama. Pancang kepala/utama dipasang pada titik ujung barat selatan blok yang akan diremajakan. Pancang rumpukan perlu dilakukan karena adanya perubahan jarak tanam lama yaitu $9.2 \times 9.2 \times 9.2$ menjadi 7.9 × 7.9 × 7.9 sehingga menyebabkan adanya perubahan jumlah populasi. Kegiatan ini memerlukan ketelitian yang sangat tinggi karena dapat mempengaruhi letak titik tanam baru dan jumlah populasi per hektarnya. Tenaga kerja yang diperlukan untuk kegiatan ini adalah 4-5 orang ditambah satu orang mandor sebagai pengawas di lapangan dengan rata-rata prestasi kerja 5 ha/HK. Alat-alat yang dibutuhkan antara lain tali seling yang telah diberi tanda sesuai ukuran yang dibutuhkan, pancang yang terbuat dari bambu atau pelepah kelapa sawit, dan kompas untuk mengetahui arah mata angin. Ilustrasi kegiatan pancang rumpuk di Seruyan Estate dapat dilihat pada Gambar 1.

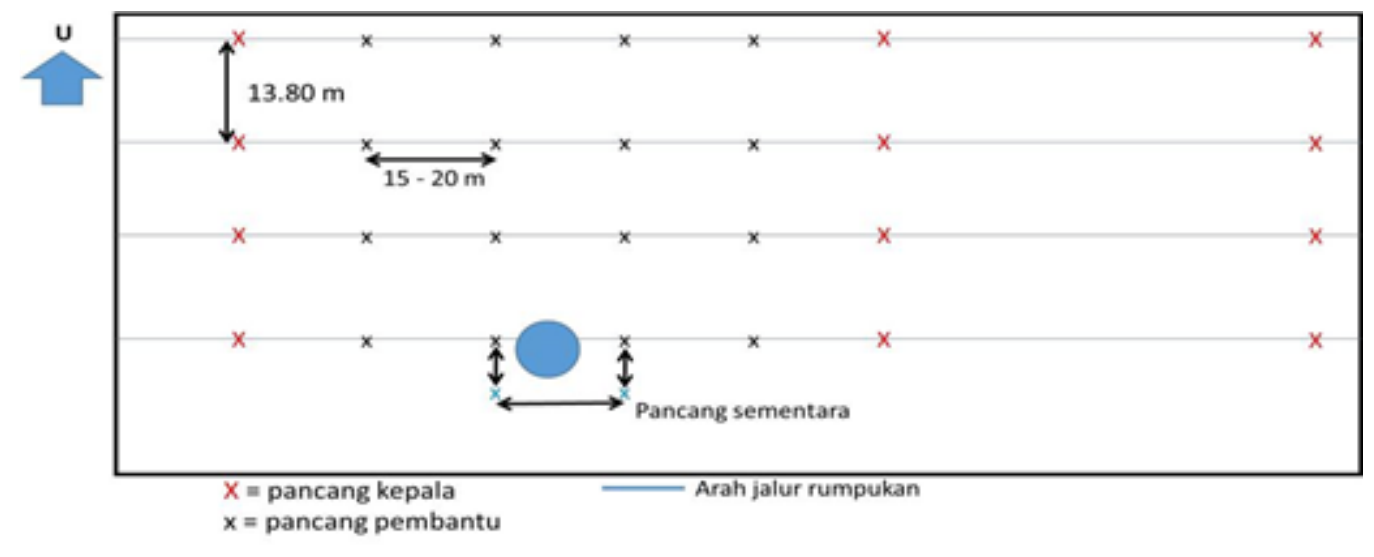

Gambar 1. Ilustrasi kegiatan pancang rumpuk

Penumbangan, Pencincangan, dan Merumpuk Pokok

Kegiatan penumbangan, pencincangan, dan merumpuk pokok merupakan suatu rangkaian yang tidak terpisahkan karena ketiga kegiatan tersebut dilakukan langsung secara berurutan di lapangan. Penumbangan pokok dilakukan dengan tujuan untuk mempermudah kegiatan pencincangan batang kelapa sawit. Kegiatan pencincangan dilakukan langsung setelah pokok kelapa sawit tumbang dengan menggunakan bucket pisau yang telah dipasang pada bucket excavator. Pencincangan ini bertujuan untuk mempercepat pelapukan pokok sawit dan menghindari perkembangbiakan Oryctes rhinoceros pada pokok yang sudah mati. Pencincangan dilakukan dari bagian bonggol akar hingga ujung pelepah. Batang kelapa sawit yang telah dicincang akan disusun rapi sesuai dengan pancang rumpuk yang telah ditentukan sebelumnya. Rumpukan ini bertujuan untuk merapikan baris tanaman, sebagai mulsa tanaman, dan bermanfaat sebagai bahan organik yang dapat menyuburkan tanaman.

Tabel 4 menunjukkan bahwa satu alat excavator rata-rata dapat menumbang, mencincang, dan merumpuk 132 pokok kelapa sawit dalam satu hari kerja. Jam kerja excavator normalnya adalah 10 HM (Hours machine) sehingga dalam satu jam, satu excavator dapat menumbang, mencincang, dan merumpuk 13 
pokok kelapa sawit. Kegiatan menumbang, mencincang, dan merumpuk dapat terhambat apabila di lapangan terjadi hujan. Kondisi lahan yang becek dapat memperberat kinerja mesin dan dapat membuat mesin menjadi cepat rusak.

Tabel 4. Prestasi kerja satu alat excavator pada kegiatan penumbangan, pencincangan, dan merumpuk pokok

\begin{tabular}{cccc}
\hline Hari ke- & $\begin{array}{c}\text { Jumlah } \\
\text { pokok }\end{array}$ & Hari ke- & $\begin{array}{c}\text { Jumlah } \\
\text { pokok }\end{array}$ \\
\hline 1 & 132 & 6 & 167 \\
2 & 126 & 7 & 101 \\
3 & 131 & 8 & 139 \\
4 & 159 & 9 & 68 \\
5 & 161 & 10 & 134 \\
\hline \multicolumn{5}{c}{ Rata - rata } \\
\hline
\end{tabular}

\section{Deboling}

Deboling adalah kegiatan pembongkaran sisa bonggol termasuk perakaran lama pokok kelapa sawit yang telah ditumbang menggunakan excavator. Ukuran penggalian lubang adalah $2 \mathrm{~m}$ x $2 \mathrm{~m}$ x $1 \mathrm{~m}$. Kegiatan ini dilakukan 1-2 minggu setelah kegiatan pencincangan selesai. Bekas galian dibiarkan terbuka selama 2 minggu dengan tujuan untuk mengangkat perakaran ke permukaan dan mengurangi potensi tumbuhnya jamur Ganoderma. Prestasi excavator dalam kegiatan ini 200 lubang/unit/hari dengan jam kerja 10 HM.

Tabel 4 menunjukkan bahwa satu alat excavator rata-rata dapat membongkar 200 lubang perakaran dalam satu hari kerja. Jam kerja excavator normalnya adalah 10 HM (Hours machine) sehingga dalam satu jam, satu excavator dapat membongkar 20 lubang bekas perakaran kelapa sawit. Seperti halnya kegiatan menumbang, mencincang, dan merumpuk, kegiatan deboling juga terhambat apabila cuaca sedang hujan. Hal ini akan memperberat kinerja mesin dan dapat membuat mesin menjadi cepat rusak.

Tabel 5. Prestasi kerja satu alat excavator pada kegiatan deboling

\begin{tabular}{cccc}
\hline Hari ke- & $\begin{array}{c}\text { Jumlah } \\
\text { lubang }\end{array}$ & Hari ke- & $\begin{array}{c}\text { Jumlah } \\
\text { lubang }\end{array}$ \\
\hline 1 & 191 & 6 & 200 \\
2 & 222 & 7 & 200 \\
3 & 216 & 8 & 228 \\
4 & 174 & 9 & 155 \\
5 & 208 & 10 & 209 \\
\hline \multicolumn{5}{c}{ Rata - rata } & 131,8 \\
\hline
\end{tabular}

\section{Pembuatan Jalan Kontur}

Pembuatan jalan kontur di kebun dilakukan dengan menggunakan bulldozer. Pembuatan jalan ini bertujuan untuk memudahkan dalam operasional pekerjaan di lapangan, terutama dalam pencatatan produksi, pengaturan organisasi kerja, pengukuran ouput kerja, dan pengawasan lapangan. Batas-batas blok diusahakan selurus mungkin, walaupun hal ini sulit diterapkan pada areal yang berbukit. Minamas Plantation (2013) menyatakan bahwa jalan dalam kebun juga tidak boleh memiliki kemiringan lebih dari $6^{0}$. Jalan yang dibuat harus tersambung dengan jalan lainnya sehingga tidak ditemukan jalan buntu dalam kebun.

Tabel 6 menunjukkan bahwa satu alat bulldozer rata-rata dapat membuat jalan kontur sepanjang $953 \mathrm{~m}$ dalam satu hari kerja. Jam kerja bulldozer normalnya adalah 10 HM (Hours machine) sehingga dalam satu jam, satu excavator dapat membuat $95 \mathrm{~m}$ jalan kontur. Seperti halnya kegiatan lainnya yang menggunakan alat berat, kegiatan deboling juga terhambat apabila cuaca sedang hujan. Hal ini akan memperberat kinerja mesin, membuat jalan menjadi susah untuk dilewati dan dibentuk, serta dapat membuat mesin menjadi cepat rusak.

Tabel 6. Prestasi kerja satu alat bulldozer pada kegiatan pembuatan jalan kontur

\begin{tabular}{cc}
\hline Hari ke- & Panjang jalan koleksi $(\mathrm{m})$ \\
\hline 1 & 955 \\
2 & 955 \\
3 & 952 \\
4 & 951 \\
5 & 951 \\
\hline Rata-rata & 953 \\
\hline
\end{tabular}

\section{Pemancangan Titik Tanam}

Pemancangan titik tanam adalah salah satu kegiatan yang terpenting dalam tahap kegiatan peremajaan karena kegiatan ini akan memberikan dampak terhadap pertumbuhan dan perkembangan tanaman kelapa sawit ke depannya. Pancang tanam bertujuan untuk memudahkan pengaturan jarak tanam dan mendapatkan populasi yang optimal dalam penanaman kelapa sawit. Kegiatan ini membutuhkan 4-5 orang tenaga ahli dengan satu orang pembidik dan satu orang mandor. Alat-alat yang dibutuhkan antara lain dua buah tali seling berukuran $150 \mathrm{~m}$ dengan satu tali seling diberi tanda setiap 3,96 m dan tali seling lainnya diberi tanda setiap $6,9 \mathrm{~m}$, pancang berukuran $2 \mathrm{~m}$ yang terbuat dari bambu atau pelepah kelapa sawit, dan kompas untuk 
mengetahui arah mata angin. Prestasi kerja pada kegiatan memancang titik tanam rata-rata adalah
$10 \mathrm{ha} / \mathrm{HK}$. Ilustrasi kegiatan pemancangan titik tanam dapat dilihat pada Gambar 2.

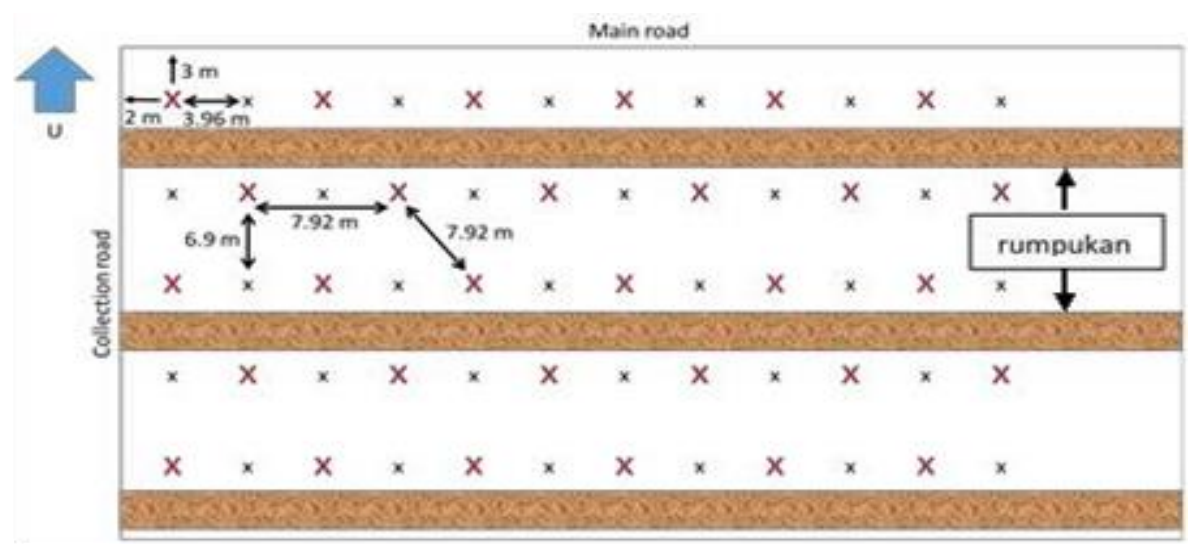

Gambar 2. Ilustrasi kegiatan pemancangan titik tanam

\section{Penanaman Kacangan Penutup Tanah}

Penanaman kacangan sebagai penutup tanah dilakukan setelah pemancangan titik tanam selesai dilakukan. Penanaman kacangan ini bertujuan untuk menutup rumpukan sehingga meminimalkan potensi perkembangbiakan hama Oryctes rhinoceros dan menjaga kelembaban tanah. Menurut Sunarko (2014), penanaman kacangan juga bertujuan untuk menekan pertumbuhan gulma, meningkatkan kandungan bahan organik tanah dan mengendalikan erosi

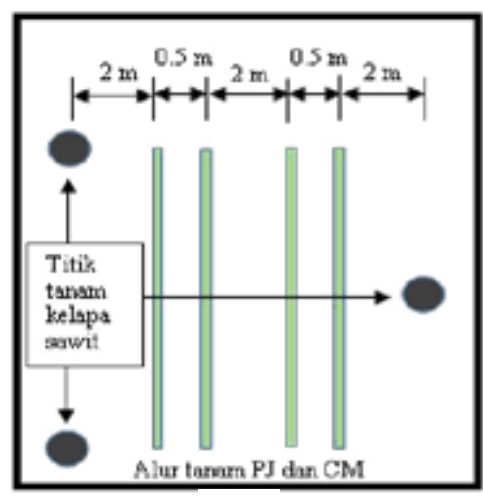

a permukaan tanah. Jenis kacangan yang digunakan di kebun Seruyan Estate antara lain adalah Pueraria javanica (PJ), Calopogonium mucunoides (CM), dan Mucuna bracteata (MB). Menurut Subronto dan Harahap (2004), Mucuna bracteata menghasilkan bahan organik yang tinggi dan akan sangat bermanfaat jika ditanam di daerah yang sering mengalami kekeringan dan pada areal yang rendah kandungan bahan organiknya. Ilustrasi penanaman kacangan penutup tanah dapat dilihat pada Gambar 3.

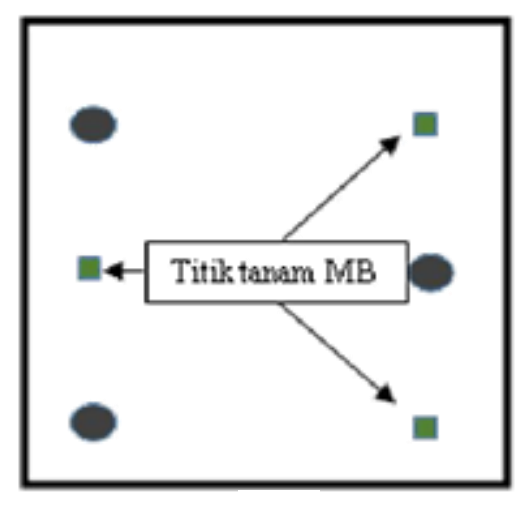

$\mathrm{b}$

(a) Alur penanaman PJ dan CM (b) titik tanam MB

Gambar 3. Ilustrasi kegiatan penanaman kacangan penutup tanah: (a) PJ dan CM, (b) MB

\section{Pembuatan Lubang Tanam}

Pembuatan lubang tanam dilakukan setelah penanaman PJ dan CM selesai dilakukan. Pembuatan lubang tanam bertujuan sebagai tempat penanaman tanaman kelapa sawit yang baru. Lubang tanam memiliki ketentuan diameter $45 \mathrm{~cm}$ dan kedalaman $60 \mathrm{~cm}$. Lubang tanam dibuat berdasarkan pancang tanam yang telah dilakukan sebelumnya. Lubang tanam digali menggunakan hole digger yang dikendalikan dengan traktor.

Tabel 7 menunjukkan bahwa satu alat hole digger rata-rata dapat menggali 870 lubang tanam dalam satu hari kerja. Jam kerja hole digger normalnya adalah 10 HM (Hours machine) sehingga dalam satu jam, satu hole digger dapat menggali 87 lubang untuk penanaman kelapa sawit. Seperti halnya kegiatan lainnya, kegiatan pembuatan lubang tanam juga terhambat apabila 
cuaca sedang hujan. Hal ini akan memperberat kinerja mesin dan dapat membuat mesin menjadi cepat rusak.

Tabel 7. Prestasi kerja satu alat hole digger pada kegiatan pembuatan lubang tanam

\begin{tabular}{cccc}
\hline Hari ke- & $\begin{array}{c}\text { Jumlah } \\
\text { lubang }\end{array}$ & Hari ke- & $\begin{array}{c}\text { Jumlah } \\
\text { lubang }\end{array}$ \\
\hline 1 & 765 & 6 & 686 \\
2 & 850 & 7 & 510 \\
3 & 1020 & 8 & 1275 \\
4 & 850 & 9 & 1156 \\
5 & 680 & 10 & 910 \\
\hline \multicolumn{5}{c}{ Rata - rata } \\
\hline
\end{tabular}

\section{Penanaman Kelapa Sawit}

Kegiatan penanaman kelapa sawit dilakukan setelah pembuatan lubang tanam selesai dilakukan. Bibit yang ditanam standarnya berumur 12 bulan dan bebas dari bibit afkir. Bibit kelapa sawit yang ditanam di Seruyan Estate adalah bibit Marihat yang berasal dari PPKS (Pusat Penelitian Kelapa Sawit) dan Socfindo yang berasal dari PT Socfindo dengan varietas Tenera. Menurut Tim Bina Karya Tani (2009), sebelum menanam, dasar lubang terlebih dahulu dipupuk dan lubang tanam diisi tanah secukupnya sampai mencapai kedalaman lubang setinggi polybag dan dilakukan pemotongan akar bibit yang menembus keluar polybag. Lubang tanam diberi pupuk rock phosphate (RP) 500 gram/pokok untuk membantu mempercepat tumbuhnya perakaran. Tanah dipadatkan dengan cara menginjak tanah di sekitar tanaman kelapa sawit hingga permukaan tanah dalam polybag sejajar dengan permukaan tanah. Hal ini bertujuan agar tanaman tidak mudah doyong atau miring apabila terkena angin. Prestasi kerja karyawan pada kegiatan penanaman kelapa sawit rata-rata adalah 100 pokok/HK yang dikerjakan oleh 10 orang tenaga kerja.

\section{Pemenuhan Kriteria RSPO dan ISPO pada Kegiatan Peremajaan}

Sesuai dengan Panduan untuk memenuhi Prinsip dan Kriteria RSPO untuk produksi minyak sawit berkelanjutan dan Permentan Republik Indonesia nomor 11/Permentan/OT.140/3/2015 tentang Sistem Sertifikasi Kelapa Sawit Berkelanjutan (ISPO), kebun Seruyan Estate tidak melakukan kegiatan peremajaan dilahan sungai dan sekitar mata air. Hal ini didukung dengan adanya areal HCV (High Conservation Value). Areal HCV merupakan areal yang didalamnya terdapat tingkat keanekaragaman hayati yang tinggi. Areal $\mathrm{HCV}$ ini juga menyebabkan berkurangnya luas areal produktif dikarenakan adanya area-area tertentu yang sudah tidak boleh ditanami kembali. Oleh karena itu, Perusahaan Minamas membuat kebijakan peningkatan populasi dalam satu hektar yang awalnya hanya 136 pokok menjadi 180 pokok di Seruyan Estate.

Bibit tanaman kelapa sawit yang ditanam saat peremajaan berasal dari benih yang bersertifikat. Hal ini dibuktikan oleh jenis bibit yang ditanam adalah bibit Marihat dari PPKS (Pusat Penelitian Kelapa Sawit) dan bibit Socfindo dari PT Socfindo . Menurut Purba et al. (2006), keunggulan bibit jenis marihat antara lain berpotensi memiliki tandan yang besar, mesokarp tebal, dan dapat ditanam di areal yang berlereng. Kebun Seruyan Estate juga mengikuti kebijakan ISPO dan RSPO yang menginginkan tidak adanya pembakaran dalam program pembukaan lahan ataupun saat kegiatan peremajaan.

\section{KESIMPULAN}

Kegiatan penelitian telah memberikan wawasan dan pengalaman kepada mahasiswa tentang kegiatan teknis dan manajerial dalam pengelolaan kebun kelapa sawit, khususnya pada aspek peremajaan kebun kelapa sawit. Peremajaan di Seruyan Estate telah dilaksanakan selama tiga tahun berturut-turut dengan prestasi kerja alat dan karyawan yang sesuai standart perusahaan. Kegiatan-kegiatan peremajaan tersebut juga dilakukan secara berurutan sesuai dengan perencanaan yang telah ditentukan.

Kebun Seruyan Estate telah memenuhi kriteria RSPO dan ISPO. Hal ini dibuktikan dengan tidak adanya kegiatan peremajaan pada areal HCV yang merupakan salah satu syarat yang harus dipenuhi oleh semua perkebunan kelapa sawit. Bibit-bibit yang dipakai pada kegiatan peremajaan juga berasal dari benih yang bersertifikat. Selain itu, peremajaan yang dilakukan oleh kebun Seruyan Estate juga mengedepankan konsep tanpa pembakaran lahan yang merupakan salah satu kriteria dalam RSPO dan ISPO.

\section{DAFTAR PUSTAKA}

Colchester, M., Jiwan, N., Andiko, S., Firdaus, M., Surambo, A.Y., Pane, H. 2006. Tanah Yang Dijanjikan. Minyak Kelapa Sawit dan Pembebasan Tanah di Indonesia: Implikasi terhadap Masyarakat Lokal dan Masyarakat Adat. Forest Peoples Programme dan Perkumpulan Sawit 
Watch.

Departemen Pertanian. 2015. Peraturan Menteri Pertanian Republik Indonesia nomor 11/Permentan/OT.140/3/2015 tentang sistem sertifikasi kelapa sawit berkelanjutan Indonesia. Departemen Pertanian, Jakarta, ID.

[Ditjenbun] Direktorat Jenderal Perkebunan. 2014. Pertumbuhan Areal Kelapa Sawit Meningkat. [internet] [diunduh 2016 Agust 13] http://ditjenbun.pertanian.go.id/

Global Sustainability Associated. 2014. Persyaratan Sistem Pengelolaan RSPO dan Panduan untuk Sertifikasi Kelompok Produksi TBS. [internet] [diunduh 2016 Jan 06] http://www.rspo.org/.

Hutasoit, F., Hutabarat, S., Muwadi, D. 2015. Analisis persepsi petani kelapa sawit swadaya bersertifikasi RSPO dalam menghadapi kegiatan peremajaan perkebunan kelapa sawit di Kecamatan Ukui, Kabupaten Pelalawan. Jurnal Faperta Vol 2 No 1. Universitas Riau. Riau, ID.

Minamas Plantation. 2013. Standard Operating Procedure: Referensi Manual Agronomi Penanaman Kelapa Sawit. Minamas Plantation, ID.

Nurkhoiry, R., Agustira, M.A., Wahyono, T., Moechtar, D., Kurniawan, A., Harahap, I.Y., Koedadri, A.D. 2006. Pedoman Norma Kerja Perkebunan Kelapa Sawit pada Lahan Mineral. Pusat Penelitian Kelapa Sawit, Medan, ID.
Pahan, I. 2008. Panduan Lengkap Kelapa Sawit: Manajemen Agribisnis dari Hulu hingga Hilir. Jakarta(ID): Penebar Swadaya.

Purba, A.R., Suprianto, E., Yenni, Y., Sujadi, Supena, N. 2006. Karakteristik Bahan Unggul PPKS dan Pola Pengelompokannya di Pembibitan. Pusat Penelitian Kelapa Sawit, Medan, ID.

Setyamidjaja, D. 2006. Seri Budidaya Kelapa Sawit. Yoyakarta(ID): Kanisius.

Subronto, Harahap, I.Y. 2004. Penggunaan Kacangan Penutup Tanah Mucuna Bracteata pada Pertanaman Kelapa Sawit. Warta Pusat Penelitian Kelapa Sawit, Medan, ID.

Sunarko. 2014. Petunjuk Praktis Budidaya dan Pengolahan Kebun Kelapa Sawit. Jakarta (ID): Agromedia Pustaka.

Susanti, E., Hutabarat, S., Muwardi, D. 2014. Analisis perbandingan alternatif model peremajaan kelapa sawit konvensional dengan underplanting pola Perkebunan Inti Rakyat (PIR) di Desa Sei Lambu Makmur, Kecamatan Tapung, Kabupaten Kampar. Jurnal Faperta Vol 1 No 2. Universitas Riau. Riau, ID.

Susanto, A., Purba, R.Y., Utomo, C.. 2006. Penyakit-Penyakit pada Kelapa Sawit. Pusat Penelitian Kelapa Sawit, Medan, ID.

Tim Bina Karya Tani. 2009. Pedoman Bertanam Kelapa Sawit. Yrama Widya, Bandung, ID. 